\title{
Localisation of a Fanconi anaemia gene to chromosome 9p
}

\author{
K athrin Saar ${ }^{1,2}$, D etlev Schindler ${ }^{4}$, R olf-D ieter Wegner ${ }^{1}$, A ndré R eis ${ }^{1,2}$, \\ Thomas F Wienker ${ }^{2}, \mathrm{H}$ olger Hoehn ${ }^{4}, \mathrm{H}$ ans Joenje ${ }^{3}, \mathrm{~K}$ arl Sperling ${ }^{1}$ and $\mathrm{M}$ artin D igweed ${ }^{1}$ \\ ${ }^{1}$ Institute of $\mathrm{H}$ uman G enetics, Charitě- Čampus Virchow-K linikum, H umboldt U niversity, B erlin \\ ${ }^{2} M$ icrosatel lite Centre, M ax D elbrück Center for M olecular M edicine, B erlin, Germany \\ ${ }^{3} \mathrm{D}$ epartment of H uman G enetics, Free U niversity, A msterdam, The N etherlands \\ ${ }^{4} \mathrm{D}$ epartment of $\mathrm{H}$ uman $\mathrm{G}$ enetics, U niversity of Würzburg, B iozentrum am H ubland, Würzburg, G ermany
}

\begin{abstract}
Using homozygosity mapping in a large consanguineous family, we have localised to chromosome $9 p$ a further gene for the autosomal recessive, genetically heterogeneous disease Fanconi anaemia (FA). This is the fourth of at least eight FA genes to be localised to a discrete chromosomal region. Previously localised genes are $F A A, F A C$ and $F A D$. By analysis of assigned families we show that the gene localised to chromosome 9p is FAF, FAG or $F A H$, or a new $F A$ gene, and refine the localisation to the $21 \mathrm{cM}$ region between markers D9S1678 and D9S175.
\end{abstract}

Keywords: Fanconi anaemia; genetic heterogeneity; homozygosity mapping; chromosome 9p

\section{Introduction}

The autosomal recessive disorder Fanconi anaemia (FA) is characterised clinically by progressive bone marrow failure, sometimes associated with skeletal abnormalities, and an increased cancer risk. Patient cells exhibit increased chromosomal breakage. ${ }^{1}$ Particularly after exposure to D NA cross-linking agents, and it has generally been assumed that this reflects a defect in a DNA repair pathway, although other explanations have been proposed (see Digweed ${ }^{2}$ and A uerbach ${ }^{3}$ for reviews).

FA shows extensive locus heterogeneity ${ }^{4}$ with currently eight complementation groups (FA-A to FA $-\mathrm{H}$ )

Correspondence: $\mathrm{M}$ artin Digweed, Institute of $\mathrm{H}$ uman Genetics, Charitě-Čampus Virchow-K linikum, H umboldt U niversity B erlin, A ugustenburger Platz 1, D-13353 Berlin, Germany. Tel: +49 30450 66016; Fax: +49 30450 66904; E-mail: digweed@ukrv.de

Received 16 A pril 1998; revised 10 June 1998; accepted 15 J une 1998 determined by somatic cell fusion and analysis of cellular sensitivity to treatment with DNA cross-linking agents. ${ }^{5}$ Three FA genes, FAA, ${ }^{6} \mathrm{FAC}^{7}$ and FAD, ${ }^{8}$ have been mapped and FAC and FAA have been cloned by expression and positional cloning strategies. ${ }^{9-11}$ It was recently possible to demonstrate that the two proteins, FAA and FAC, associate to form a complex which is localised to both cell cytoplasm and cell nucleus. ${ }^{12}$ A Ithough the function of this protein complex is as yet unknown, the finding that $F A C$ also associates with the cyclin dependent kinase $p 34^{\text {cdc2 }}$ suggests that cell cycle regulation may be involved. ${ }^{13}$ Indeed, other studies have suggested an involvement of cyclins in the cellular phenotype of FA. ${ }^{14,15}$

The lack of significant global homology of FAA or FAC to known proteins has hampered the elucidation of the basic defect in this disorder. Thus the cloning of further FA genes is of considerable importance, not only for diagnostic purposes, but also in the expectation that they will show homology to known proteins and 
thus help define the primary pathway affected in FA. O ne approach to this goal is the chromosomal localisation of other FA genes.

We have established such a chromosomal localisation for an FA gene on chromosome $9 p$ by homozygosity mapping in a consanguineous family which had not previously been assigned to a complementation group. By linkage analysis we show that this gene is not the gene for $F A$ complementation groups $A$ to $E$. A nalysis of two further $F A$ families, similarly excluded from groups $A$ to $E$, is compatible with this localisation and allows refinement to a $21 \mathrm{cM}$ region between markers D 9S1678 and D 9S175.

\section{Materials and Methods}

\section{Families}

A II patients described were diagnosed on the basis of their chromosomal hypersensitivity to DNA cross-linking agents. The five families analysed are referred to here as families I to $V$. The large consanguineous family I (patients FA 15BE R and FA 23BER) has not been previously assigned to a complementation group. The L ebanese parents are first cousins once removed. Family II (patient EUFA 178) has been assigned to group B. ${ }^{16}$ The Turkish parents in family III are first cousins and their affected child (EUFA 130) is the reference group $\mathrm{E}$ patient. ${ }^{17,18}$

In Family IV there are two affected children (patients E U FA 348 and E U FA 349). Family V has two affected children (E U FA 316); fibroblasts of an affected aborted foetus, diagnosed prenatally on the basis of $M$ itomycin $C$ induced chromosome breakage, were also available. Families IV and $\mathrm{V}$ have been excluded from groups A, B, C, D and E by cell fusion and complementation analysis ( $H$ Joenje 1998 unpublished results). Pedigrees of these five families are shown in Figures 2 and Figure 3.

Where possible, lymphoblastoid cell lines were established by EBV transformation at the Departments of $H$ uman G enetics in A msterdam or W ürzburg. DNA was extracted from blood or from lymphoblastoid cells by standard techniques.

\section{Microsatellite Analysis}

In the initial homozygosity search, the parents and the two affected children of family I were analysed. The haplotypes of the homozygous regions of chromosome 7 and chromosome 9 were then examined for the seven unaffected children, and the other four families. The microsatellite markers were from the MDC-G énéthon mapping panel with an average spacing of $11 \mathrm{cM}$. M arkers were amplified by PCR using fluorescently labelled primers and analysed on the Pharmacia ALF (Freiburg, Germany) or A BI 377 (Weiterstadt, Germany) sequencers. L ength determination was carried out using an internal standard with the Genescan 1.2 and Genotyper software.

\section{Linkage Analysis}

Version 5.1 of the LINKAGE software was used to calculate pairwise lod scores between the disease and marker loci assuming a fully penetrant autosomal recessive mode of inheritance and uniform allele frequencies. All genotypes were checked for Mendelian inheritance using the LINKRUN program. For the two consanguineous families, I and III, loops were broken at the fathers.

\section{Results}

\section{Exclusion of FA-A, FA-C and FA-D}

The starting point for the localisation reported here was a locally resident, consanguineous family of L ebanese origin with two children affected with FA (Figure2, pedigree I). I nitial diagnosis was based on clinical and haematological findings and was confirmed by the analysis of chromosomal breakage after treatment with a trifunctional alkylating agent (data not shown). Three attempts to establish a permanently transformed lymphoblastoid cell line from the affected children failed,

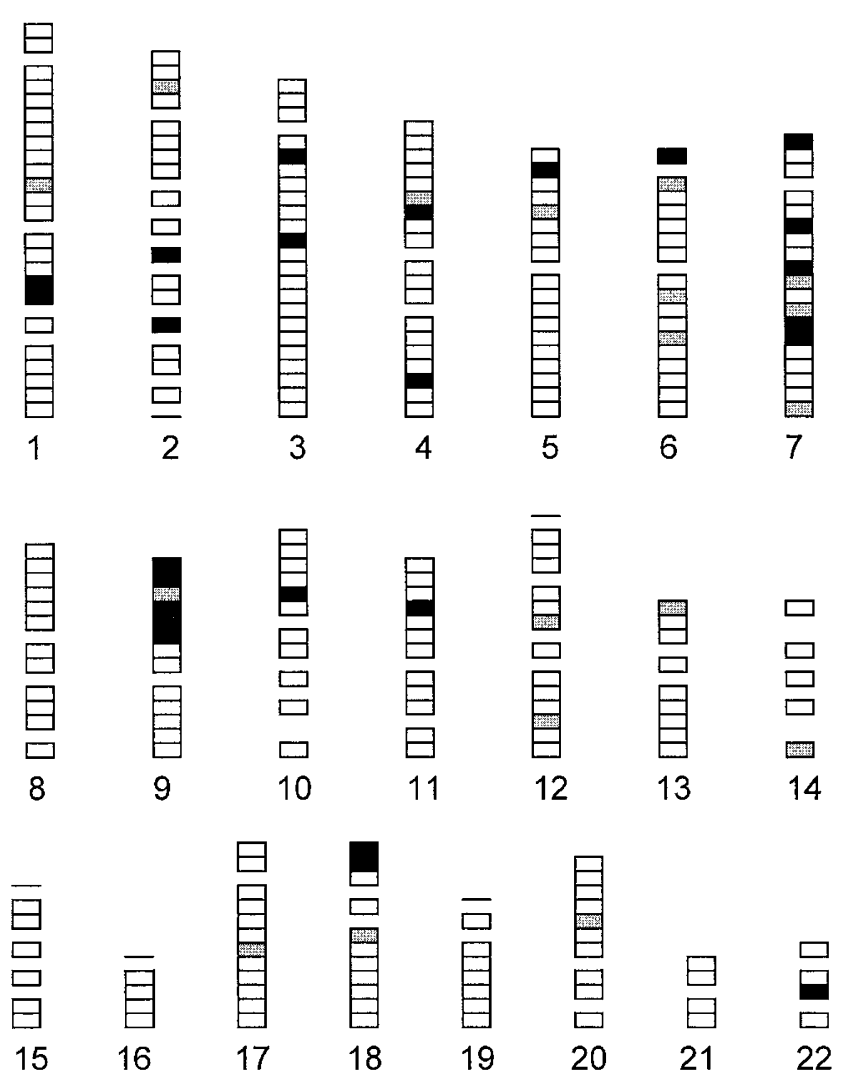

Figure 1 H omozygosity mapping of 269 microsatel lite markers spaced at $11 \mathrm{cM}$ intervals in Fanconi anaemia family $\mathrm{I}$. $\mathrm{E}$ ach box represents a microsatellite marker located on the 22 autosomes; black boxes indicate markers that were informative and homozygous in both affected children; shaded boxes are markers that were homozygous in both affected children but not informative; white boxes were markers that were heterozygous in at least one of the two affected children; missing boxes are markers that were not analysed. 

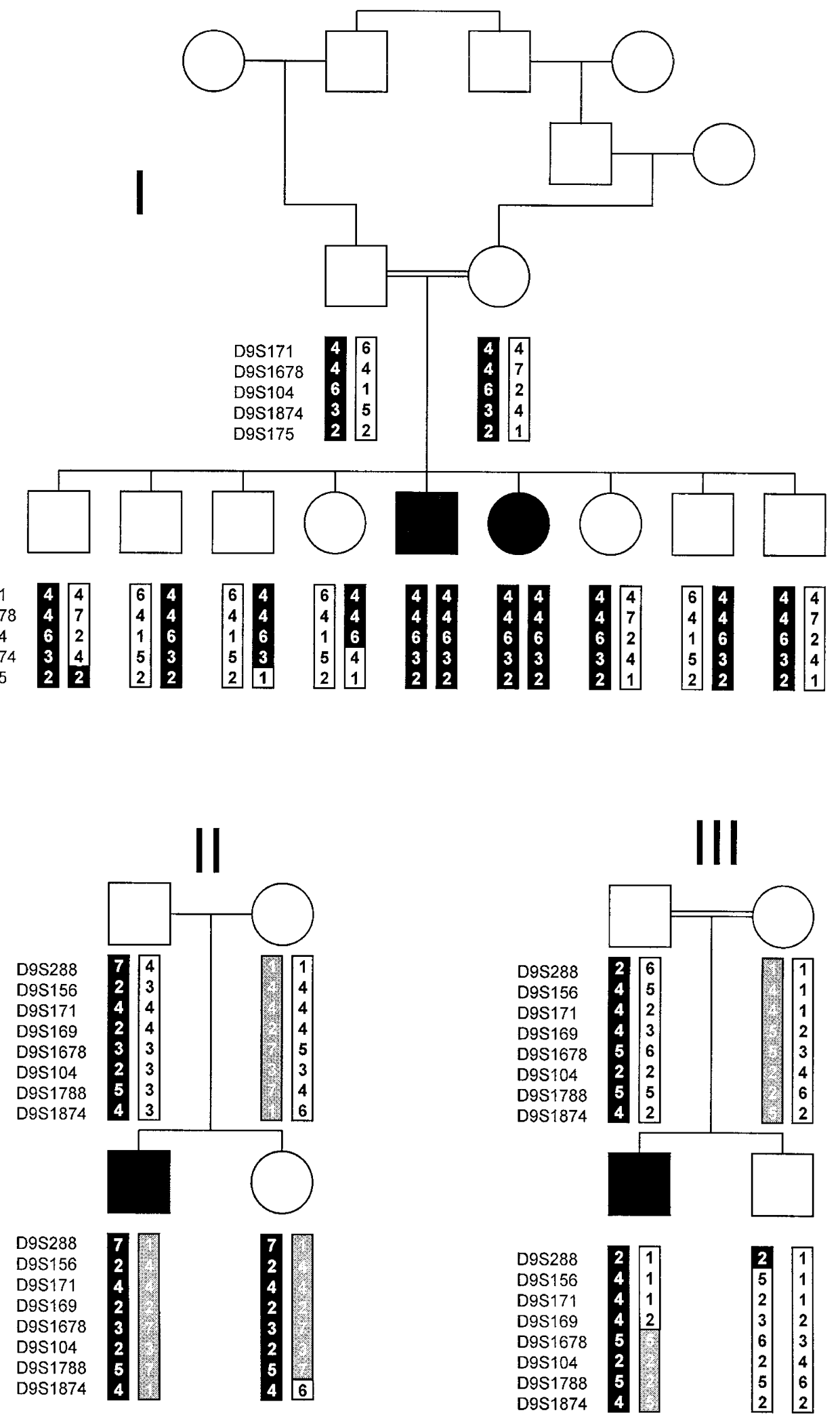

Figure 2 Most likely haplotypes for microsatellite markers on chromosome $9 \mathrm{p}$. I: the large consanguineous $L$ ebanese family not previously assigned to a complementation group; II: a family assigned to complementation group $\mathrm{B} ;{ }^{16} \mathrm{III}$ : the reference group $\mathrm{E}$ family; ${ }^{17}$ symbols of affected individuals are filled. 

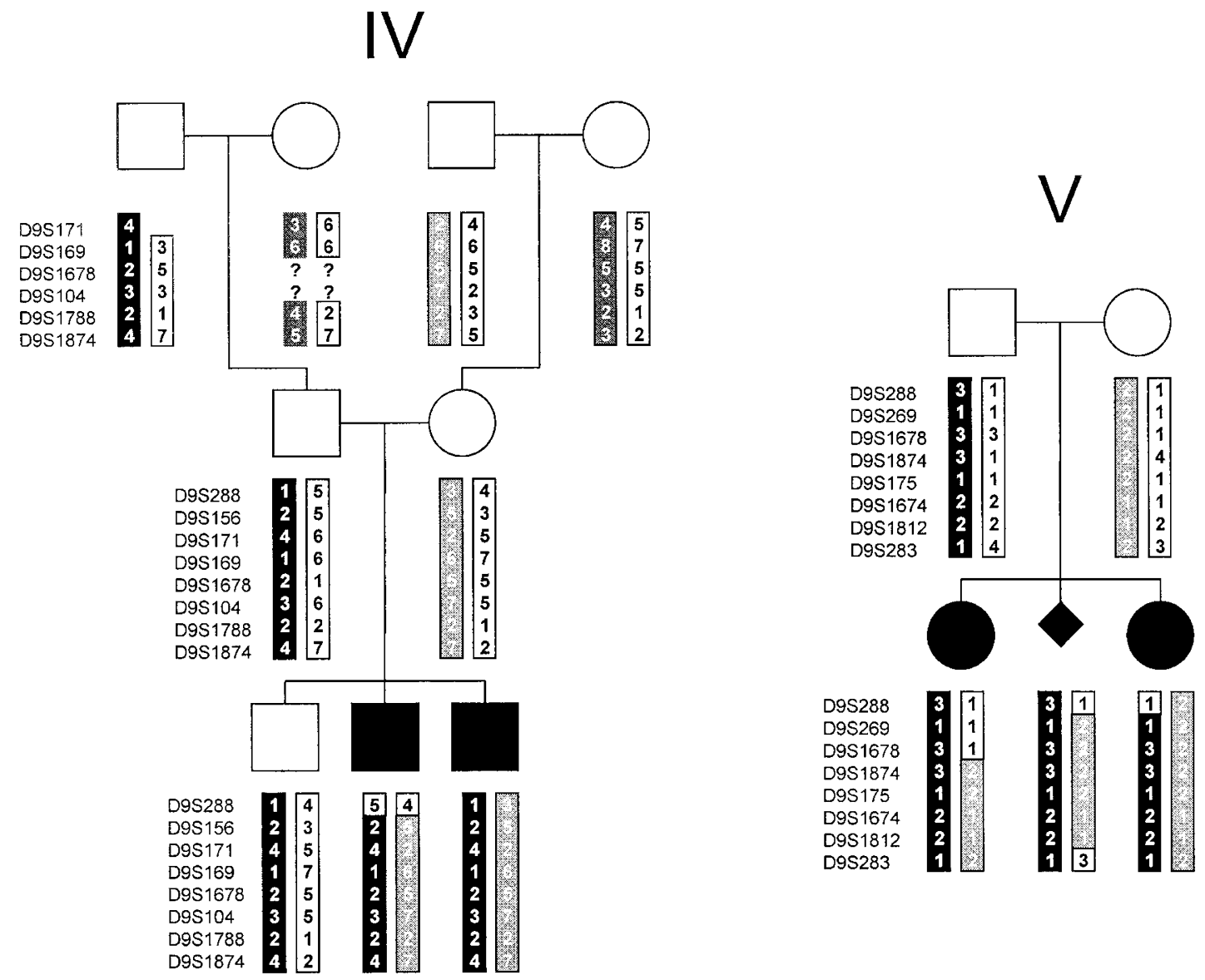

Figure 3 Most likely haplotypes for microsatellite markers on chromosome 9p: Non-A, B, C, D, E families. IV and V are families assigned to complementation group $\mathrm{F}, \mathrm{G}$ or $\mathrm{H}$ by somatic cell fusion; symbols of affected individuals are filled. ?: not typed.

so that somatic cell fusion for complementation group analysis, as usually carried out for FA patients, was not possible. A n assignment to one of the known complementation groups, $A-H$, could therefore only be made based on the chromosomal locations of FA genes.
Chromosomal localisations for the FAA, FAC and FAD genes have been reported. ${ }^{6-8} \mathrm{~A} n$ analysis of linkage in family I with marker D 16S413, located 4 cM from the FAA gene, excluded a mutation in the FAA gene for this family (Table 1). Similarly, analysis with markers D $9 S 283$ and D 9S53, which flank the FAC gene,

Table 1 Pairwise LOD scores for an FA locus in family I and microsatellite markers on chromosome 3p, 9q and 16q

\begin{tabular}{|c|c|c|c|c|c|c|c|c|c|}
\hline \multirow[b]{2}{*}{ M arker } & \multicolumn{7}{|c|}{ Recombination fractions $(\theta)$} & \multirow[b]{2}{*}{$\mathrm{Z}_{\max }$} & \multirow[b]{2}{*}{$\theta_{\max }$} \\
\hline & 0.000 & 0.001 & 0.010 & 0.050 & 0.100 & 0.200 & 0.300 & & \\
\hline $\begin{array}{l}\text { D 3S1297 } \\
\text { D 3S1560 } \\
\text { D 3S1597 } \\
\text { D 3S1286 } \\
\text { D 3S1266 } \\
\text { D 3S1298 }\end{array}$ & $\begin{array}{r}-99.999 \\
-99.999 \\
-2.324 \\
-99.999 \\
0.573 \\
-99.999\end{array}$ & $\begin{array}{r}-4.968 \\
-3.727 \\
-2.172 \\
8.667 \\
0.573 \\
-5.269\end{array}$ & $\begin{array}{r}-1.535 \\
-1.713 \\
-0.709 \\
-3.223 \\
0.560 \\
-1.829\end{array}$ & $\begin{array}{r}-0.343 \\
-0.966 \\
-0.097 \\
-1.291 \\
0.507 \\
-0.608\end{array}$ & $\begin{array}{r}0.010 \\
-0.625 \\
0.100 \\
-0.589 \\
0.439 \\
-0.209\end{array}$ & $\begin{array}{r}0.132 \\
-0.288 \\
0.179 \\
-0.096 \\
0.303 \\
0.022\end{array}$ & $\begin{array}{r}0.070 \\
-0.119 \\
0.125 \\
0.023 \\
0.175 \\
0.047\end{array}$ & $\begin{array}{l}0.134 \\
- \\
0.179 \\
- \\
0.573 \\
-\end{array}$ & $\begin{array}{l}0.187 \\
- \\
0.192 \\
- \\
0.000 \\
-\end{array}$ \\
\hline $\begin{array}{l}\text { D 9S283 } \\
\text { D } 9 S 53\end{array}$ & $\begin{array}{l}-99.999 \\
-99.999\end{array}$ & $\begin{array}{l}-2.999 \\
-9.424\end{array}$ & $\begin{array}{l}-0.988 \\
-3.459\end{array}$ & $\begin{array}{l}-0.364 \\
-1.507\end{array}$ & $\begin{array}{l}-0.153 \\
-0.786\end{array}$ & $\begin{array}{l}-0.021 \\
-0.240\end{array}$ & $\begin{array}{r}0.004 \\
-0.051\end{array}$ & $\overline{0} 011$ & $-\overline{0.437}$ \\
\hline D $16 S 413$ & -99.999 & -6.297 & -2.821 & -1.457 & -0.895 & -0.386 & -0.147 & - & - \\
\hline
\end{tabular}


excluded membership of this group for this family (Table 1). The localisation of the FAD gene to chromosome $3 p$ was relatively imprecise so that we elected to look for linkage by homozygosity mapping. ${ }^{9}$ Six markers covering $70 \mathrm{cM}$ on chromosome $3 p$, including the critical FAD region, ${ }^{8}$ were examined. The pairwise lod scores in Table 1 show the results of this analysis, which clearly excluded group D.

\section{Homozygosity Mapping}

Since no further chromosomal localisations for FA genes were known, we ran a genome-wide analysis for homozygosity expecting to find a large overlapping region of homozygous markers covering around $30 \mathrm{cM}$ in the two affected children. A fter excluding approximately $87 \%$ of the genome by analysing 269 microsatellite markers, we found two regions to be homozygous in the two affected children (Figures 1 ). O ne region of maximally $53 \mathrm{cM}$ on chromosome $7 q$, between D 7S479 and D 7S661, could be excluded by haplotype analysis of the seven unaffected children (data not shown). The other region, $73.5 \mathrm{cM}$ on chromosome 9 , between pter and marker D9S167, proved to be homozygous only in the two affected children, except for D9S175 which was also homozygous, due to a crossover, in an unaffected child (Figure 2, pedigree I). This reduces the critical region to $61.2 \mathrm{cM}$ from pter to D 9S175. The maximum overall pairwise lod score is $Z_{\text {max }}=2.282$ at $\theta=0.00$ for marker D $9 S 1874$ (Table 2a).

For homozygosity mapping, calculation of lod scores for entire haplotypes is appropriate. ${ }^{19}$ For this, the haplotype, 4-4-6-3, at D 9S171-D 9S1678D 9S104-D $9 S 1874$ was considered as a single marker with a frequency of 0.00003 calculated from the individual frequencies of alleles at these markers. The maximum lod score based on this haplotype is $Z_{\text {max }}=2.68$ at $\theta=0.00$. This convincingly suggested that the FA gene mutated in this family is located on chromosome 9p.

\section{Analysis of FA-B and FA-E Families}

In order to establish which complementation group is involved we examined whether the hitherto unmapped $F A B$ and $F A E$ genes might be localised in this region.

Complementation group $B$ is represented worldwide by just two families, one is the German family shown in Figure2, pedigree II. As shown by the haplotypes in the figure, the FAB gene can be clearly excluded from the majority of the critical region of chromosome $9 p$, since both the affected and unaffected child have inherited the same chromosomes from marker D 9S288 to D 9S1788. A recombination event in the maternal meiosis of the unaffected child results in a different allele combination at D 9S1874 so that this last marker cannot be excluded (Table $2 b$ ).

The reference patient for the group $F A E$ is EUFA 130, the affected child of a consanguineous family of Turkish origin ${ }^{18}$ (Figure 2, pedigree III and Table 2b). A s shown in Figure2, only two markers on chromosome $9 p$ are homozygous in the affected child. This gives a homozygous region of $9.1 \mathrm{cM}$, much less than the $30 \mathrm{cM}$ expected for progeny of first cousins. ${ }^{20}$ Furthermore, the region of common haplotype is no larger in the parents, where an uninterrupted common region of $60 \mathrm{~cm}$ could be expected for first cousins. This makes it highly unlikely that a gene in this region is responsible for FA in this family. We are currently extending the search for homozygous regions in this family.

\section{Further FA Families Link to Chromosome 9p}

Since the gene localised by linkage in the large family I is not one of the genes FA -A to FA - $E$, we analysed two further families similarly excluded from groups $A$ to $E$ on the basis of cell fusion and complementation analysis. In Figure 3, pedigrees IV and V, two families are shown together with the deduced haplotypes for this chromosomal region. Clearly both these families are compatible with an FA gene on chromosome $9 \mathrm{p}$. The maximum pairwise lod scores are $Z_{\max }=0.727$ at $\theta=0.00$ in family IV and $Z_{\max }=1.204$ at $\theta=0.00$ in family V, in both cases for marker D 951874 (Table 2a). Figure 4 shows chromosome $9 p$ with the maximal region for the FA gene localised in this report.

\section{Discussion}

Fanconi anaemia is a rare disorder with an extreme degree of genetic heterogeneity, consequently for some complementation groups only a few families will be identified and localisation of the causative genes will only be possible by employing highly informative techniques such as homozygosity mapping. This method exploits the observation that an affected child of consanguineous parents will be homozygous by descent for a region of many centimorgans surrounding the disease gene. ${ }^{20}$ We have examined a large consanguineous family in this way and demonstrate that an FA gene must be located on chromosome 9p. A though the maximal lod score achieved with this family is below 
23

22.3

21.3

21.2

21.1
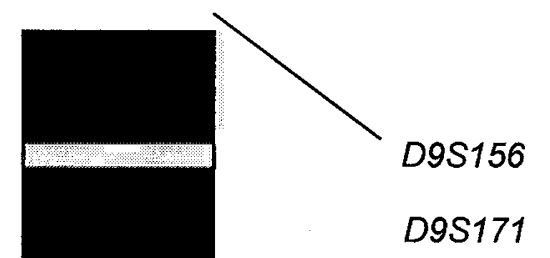

$12.5 \mathrm{cM}$

(2)

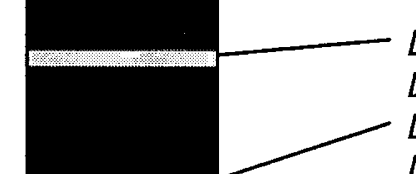

D9S169 D9S1678

D9S104 D9S1788

13.3

13.2

13.1

12

11.2

11.1

12

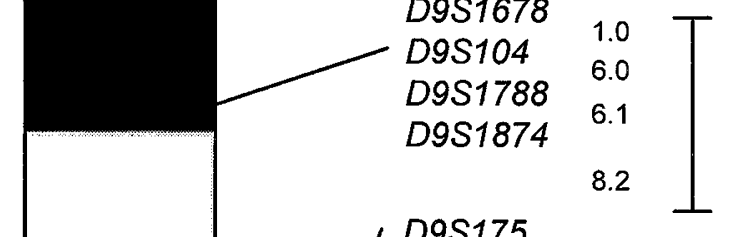

Figure $4 \mathrm{M}$ ap of microsatellite markers on chromosome $9 p$. $G$ enetic distances are indicated in centimorgans $(\mathrm{CM}) .^{24}$ Physical locations of key markers are taken from the consensus map of chromosome $9 p^{23}$ the level normally required for significance in linkage studies, it must in fact be compared with the much lower likelihood of the random meeting of two independent alleles. The parents are first cousins once removed. This equates to a fraction of $1 / 32$ of each child's genome being homozygous. In comparison, the FA allele frequency is approximately $q=0.002 .{ }^{21}$

A homozygous region of approximately $30 \mathrm{cM}$ would be expected at this level of consanguinity. ${ }^{20} \mathrm{O}$ nly one such homozygous chromosomal region could be identified in both affected children after excluding over $87 \%$ of the genome in this family. Interestingly, a previous study, using eight consanguineous FA families which did not link to markers around the FA gene also suggested an FA gene on chromosome $9 p^{22}$

A nalysis of assigned families has proven that the FA gene on chromosome $9 p$ is not that of FA group A, C, $D$ or $E$ and unlikely to be that of group $B$. Two further FA families also show positive lod scores with markers on chromosome 9p. We have no further grounds for combining lod scores of these three families other than their exclusion from the same complementation groups either by linkage (family I) or by cell fusion analyses (families IV and V); considering the genetic heterogeneity of FA, such a combination must be viewed with caution. However, bearing in mind this caveat, the three families together yield a lod score of 4.214 at $\theta=0$ for D $9 S 1874$ in chromosomal band $9 \mathrm{p} 12-13.3^{23}$

Table 2a Pairwise LOD scores for an FA locus and markers on chromosome 9p in unassigned family (I) and two families, IV and $\mathrm{V}$, excluded from complementation groups $\mathrm{A}-\mathrm{E}$

\begin{tabular}{|c|c|c|c|c|c|c|c|}
\hline \multirow[b]{2}{*}{ M arker } & \multicolumn{7}{|c|}{ Recombination fractions $(\theta)$} \\
\hline & Family & 0.000 & 0.010 & 0.050 & 0.100 & 0.200 & 0.300 \\
\hline D 9S156 & IV & $\begin{array}{l}0.398 \\
0.727\end{array}$ & $\begin{array}{l}0.384 \\
0.705\end{array}$ & $\begin{array}{l}0.329 \\
0.618\end{array}$ & $\begin{array}{l}0.264 \\
0.510\end{array}$ & $\begin{array}{l}0.149 \\
0.306\end{array}$ & $\begin{array}{l}0.064 \\
0.140\end{array}$ \\
\hline D $9 S 171$ & IV & $\begin{array}{l}0.833 \\
0.727\end{array}$ & $\begin{array}{l}0.814 \\
0.705\end{array}$ & $\begin{array}{l}0.740 \\
0.618\end{array}$ & $\begin{array}{l}0.643 \\
0.510\end{array}$ & $\begin{array}{l}0.448 \\
0.306\end{array}$ & $\begin{array}{l}0.266 \\
0.140\end{array}$ \\
\hline D $9 S 1678$ & $\begin{array}{l}\text { I } \\
\text { IV } \\
\text { V }\end{array}$ & $\begin{array}{r}0.631 \\
0.125 \\
-99.999\end{array}$ & $\begin{array}{r}0.618 \\
0.121 \\
-1.402\end{array}$ & $\begin{array}{r}0.563 \\
0.104 \\
-0.721\end{array}$ & $\begin{array}{r}0.491 \\
0.084 \\
-0.444\end{array}$ & $\begin{array}{r}0.341 \\
0.049 \\
-0.194\end{array}$ & $\begin{array}{r}0.202 \\
0.023 \\
-0.076\end{array}$ \\
\hline D 9S104 & IV & $\begin{array}{l}2.215 \\
0.727\end{array}$ & $\begin{array}{l}2.153 \\
0.705\end{array}$ & $\begin{array}{l}1.906 \\
0.618\end{array}$ & $\begin{array}{l}1.604 \\
0.510\end{array}$ & $\begin{array}{l}1.033 \\
0.306\end{array}$ & $\begin{array}{l}0.537 \\
0.140\end{array}$ \\
\hline D $9 S 1874$ & $\begin{array}{l}\text { I } \\
\text { IV }\end{array}$ & $\begin{array}{l}2.282 \\
0.727 \\
1.204\end{array}$ & $\begin{array}{l}2.224 \\
0.705 \\
1.178\end{array}$ & $\begin{array}{l}1.990 \\
0.618 \\
1.071\end{array}$ & $\begin{array}{l}1.701 \\
0.510 \\
0.931\end{array}$ & $\begin{array}{l}1.142 \\
0.306 \\
0.636\end{array}$ & $\begin{array}{l}0.637 \\
0.140 \\
0.341\end{array}$ \\
\hline D $9 S 175$ & l & $\begin{array}{l}0.777 \\
0.602\end{array}$ & $\begin{array}{l}0.760 \\
0.589\end{array}$ & $\begin{array}{l}0.689 \\
0.535\end{array}$ & $\begin{array}{l}0.597 \\
0.465\end{array}$ & $\begin{array}{l}0.414 \\
0.318\end{array}$ & $\begin{array}{l}0.244 \\
0.170\end{array}$ \\
\hline D 9S1674 & V & 0.602 & 0.589 & 0.535 & 0.465 & 0.318 & 0.170 \\
\hline D $9 S 1812$ & V & 0.602 & 0.589 & 0.535 & 0.465 & 0.318 & 0.170 \\
\hline D 9S283 & V & -99.999 & -0.813 & -0.186 & 0.022 & 0.124 & 0.095 \\
\hline
\end{tabular}


Table $\mathbf{2 b}$ Pairwise LOD scores for an FA locus and markers on chromosome $9 p$ in complementation group B family (II) and complementation group $\mathrm{E}$ family III

\begin{tabular}{|c|c|c|c|c|c|c|c|c|}
\hline \multirow[b]{2}{*}{ M arker } & \multicolumn{8}{|c|}{ Recombination fractions $(\theta)$} \\
\hline & Family & 0.000 & 0.001 & 0.010 & 0.050 & 0.100 & 0.200 & 0.300 \\
\hline \multirow[t]{2}{*}{ D 9S156 } & II & -0.176 & -0.175 & -0.168 & -0.137 & -0.104 & -0.056 & -0.024 \\
\hline & III & -2.924 & -0.962 & -0.344 & -0.138 & -0.012 & 0.013 & 0.012 \\
\hline \multirow[t]{2}{*}{ D 9S169 } & II & -99.99 & -2.274 & -1.282 & -0.617 & -0.360 & -0.145 & -0.053 \\
\hline & III & -2.773 & -1.155 & -0.527 & -0.299 & -0.120 & -0.045 & -0.010 \\
\hline \multirow[t]{2}{*}{ D $9 S 1678$} & II & -0.176 & -0.175 & -0.168 & -0.137 & -0.104 & -0.056 & -0.024 \\
\hline & III & 0.901 & 0.877 & 0.782 & 0.665 & 0.442 & 0.251 & 0.104 \\
\hline \multirow[t]{2}{*}{ D 9S104 } & II & -0.176 & -0.175 & -0.168 & -0.137 & -0.104 & -0.056 & -0.024 \\
\hline & III & 0.662 & 0.642 & 0.563 & 0.467 & 0.294 & 0.157 & 0.062 \\
\hline \multirow{2}{*}{ D 9S1788 } & II & -99.99 & -2.274 & -1.282 & -0.617 & -0.360 & -0.145 & -0.053 \\
\hline & III & -2.773 & -1.151 & -0.509 & -0.271 & -0.089 & -0.026 & -0.004 \\
\hline \multirow[t]{2}{*}{ D $9 S 1874$} & II & 0.125 & 0.124 & 0.116 & 0.086 & 0.056 & 0.018 & 0.004 \\
\hline & III & -2.732 & -1.342 & -0.690 & -0.434 & -0.223 & -0.133 & -0.072 \\
\hline
\end{tabular}

and the recombination events in family $\mathrm{V}$ would reduce the critical region to the $21 \mathrm{cM}$ between D $9 S 1678$ and D 9 S175.

The localisation of a further FA gene to a discrete chromosomal region reconfirms the genetic heterogeneity of this disease. At this stage it is unclear what proportion of FA cases will be due to a mutation of the FA gene on chromosome $9 \mathrm{p}$. If the analysis presented here in which two German and one Lebanese family localise to chromosome $9 p$ is representative, then this may not be one of the rarest FA genes. The chromosomal localisation reported here will have consequences for diagnosis of FA and may provide a basis for identifying another FA gene.

\section{Acknowledgements}

We are pleased to acknowledge the help of the German Fanconi anaemia support group and Dr B. Schmolenberger, D r U sula Schulte-Overberg (B erlin) and Dr Wolfram E bell (B erlin) for referring patients to us. We thank M s A lexandra Förster for excellent technical assistance. This work was assisted by EU FA R , a C oncerted A ction for Fanconi anaemia research sponsored by the Commission of the European Union.

\section{References}

1 Schroder TM , A nschütz F, K nopp A : Spontane Chromosomenaberrationen bei familiärer Panmyelopathie. H umangenetik 1964; 1: 194-196.

2 Digweed M, Sperling K: M olecular analysis of Fanconi anemia . Bioessays 1996; 18: 579-585.
3 A uerbach A D, B uchwald M, Joenje $\mathrm{H}$ : Fanconi anemia In Vogelstein B, Kinzler KW (eds): The Genetic Basis of Human Cancer McGraw-Hill: New York, 1998, pp 317-332.

4 Zakrzewski S, Sperling K: Genetic heterogeneity of Franconi's anaemia demonstrated by somatic cell-hybrids. H um G enet 1980; 56: 81-84.

5 J oenje $H, O$ ostra $A B, W$ ijker $M$ et al: Evidence for at least eight Fanconi anemia genes. A m J Hum G enet 1997; 61: 940-944.

6 Pronk J, Gibson RA, Savoia A et al: Localisation of the Fanconi anaemia complementation group $A$ gene to chromosome 16q24.3. N at G enet 1995; 11: 338-340.

7 Strathdee CA, D uncan A M , B uchwald M : E vidence for at least four Fanconi anaemia genes including $F A C C$ on chromosome 9. N at G enet 1992; 1: 196-198.

8 Whitney $M$, Thayer $M$, Reifsteck $C$ et al: $M$ icrocell mediated chromosome transfer maps the Fanconi anaemia group D gene to chromosome 3p. N at Genet 1995; 11: 341-343.

9 Strathde CA, Gavish $H$, Shannon WR, Buchwald M: Cloning of CDNA S for Fanconi's anaemia by functional complementation. N ature 1992; 356: 763-767.

10 Lo Ten Foe J R, R ooimans M A, B osnoyan-Collins L et al: Expression cloning of a CDNA for the major Fanconi anaemia gene, FA A. Nat G enet 1996; 14: 320-323.

11 The Fanconi anaemia/Breast cancer consortium. Positional cloning of the Fanconi anaemia group $\mathrm{A}$ gene. $\mathrm{N}$ at Genet 1996; 14: 324-328.

12 Kupfer GM, Naf D, Suliman D, Pulsipher M, D'A ndrea $A D$ : The Fanconi anaemia proteins, FAA and FAC, interact to form a nuclear complex. Nat G enet 1997; 17: 487-490.

13 Kupfer G M, Yamashita T, Naf D, Suliman A, A sano S, $D$ 'A ndrea AD: The Fanconi anemia polypeptide, FAC, binds to the cyclin-dependent kinase, cdc2. Blood 1997; 90: 1047-1054.

14 D igweed M, G ünthert U, Schneider R, Seyschab H, Friedl $R$, Sperling $K$ : I rreversible repression of D NA synthesis in Fanconi anaemia cells is alleviated by the product of a novel cyclin-related gene. Mol Cell Biol 1995; 15: 305-314. 
15 K ruyt FA, Dijkmans LM, A rwert $F$, Joenje $H$ : Involvement of the Fanconi's anemia protein FAC in a pathway that signals to the cyclin B/cdc2 kinase. Cancer Res 1997; 57: 2244-2251.

16 Joenje $\mathrm{H}$ : Fanconi anemia complementation groups in Germany and the Netherlands. Hum Genet 1995; 97: 280-282.

17 J oenje H, L o Ten Foe J R, O ostra A B et al: Classification of Fanconi anemia patients by complementation analysis: evidence for a fifth genetic subtype. Blood 1995; 86: 2156-2160.

18 Wegner RD, H enrichs I, J oenje H, Schroeder-K urth TM : Fanconi anemia complementation group $\mathrm{E}$ : clinical and cytogenetic data of the first patient. Clin G enet 1996; 30: 479-482.

19 Ben Hamida C, Doerflinger N, B elal S et al: Localisation of Friedrich ataxia phenotype with selective vitamin $E$ deficiency to chromosome $8 q$ by homozygosity mapping. $\mathrm{N}$ at G enet 1993; 5: 195-200.
20 Lander E S, B otstein D : H omozygosity mapping: a way to map human recessive traits with the DNA of inbred children. Science 1987; 236: 1567-1570.

21 Swift M: Fanconi's anaemia in the genetics of neoplasia. Nature 1971; 230: 370-373.

22 G schwend M, Levran O, Kruglyak L et al: A locus for Fanconi anemia on $16 q$ determined by homozygosity mapping. A m J Hum G enet 1996; 59: 377-384.

23 Povey S, A ttwood J, Chadwick B et al: R eport on the Fifth International Workshop on Chromosome 9 held at $E$ ynsham, Oxfordshire, UK, September 4-6, 1996. A nn H um G enet 1997; 61: 183-206.

$24 \mathrm{Dib} C$ et al: A comprehensive genetic map of the human genome based on 5,264 microsatellites. N ature 1996; 380: 152-154. 